\title{
Shifting Plaintiffs' Fees versus Increasing Damage Awards
}

\section{Citation}

Louis Kaplow, Shifting Plaintiffs' Fees versus Increasing Damage Awards, 24 RAND J. Econ. 625 (1993).

\section{Published Version}

http://www.jstor.org/stable/2555749

\section{Permanent link}

http://nrs.harvard.edu/urn-3:HUL.InstRepos:12206466

\section{Terms of Use}

This article was downloaded from Harvard University's DASH repository, and is made available under the terms and conditions applicable to Other Posted Material, as set forth at http:// nrs.harvard.edu/urn-3:HUL.InstRepos:dash.current.terms-of-use\#LAA

\section{Share Your Story}

The Harvard community has made this article openly available.

Please share how this access benefits you. Submit a story.

\section{Accessibility}




\section{(W) WILEY-}

\section{The RAND Corporation}

Shifting Plaintiff's' Fees versus Increasing Damage Awards

Author(s): Louis Kaplow

Source: The RAND Journal of Economics, Vol. 24, No. 4 (Winter, 1993), pp. 625-630

Published by: Blackwell Publishing on behalf of The RAND Corporation

Stable URL: http://www.jstor.org/stable/2555749

Accessed: 14/03/2010 16:46

Your use of the JSTOR archive indicates your acceptance of JSTOR's Terms and Conditions of Use, available at http://www.jstor.org/page/info/about/policies/terms.jsp. JSTOR's Terms and Conditions of Use provides, in part, that unless you have obtained prior permission, you may not download an entire issue of a journal or multiple copies of articles, and you may use content in the JSTOR archive only for your personal, non-commercial use.

Please contact the publisher regarding any further use of this work. Publisher contact information may be obtained at http://www.jstor.org/action/showPublisher?publisherCode=black.

Each copy of any part of a JSTOR transmission must contain the same copyright notice that appears on the screen or printed page of such transmission.

JSTOR is a not-for-profit service that helps scholars, researchers, and students discover, use, and build upon a wide range of content in a trusted digital archive. We use information technology and tools to increase productivity and facilitate new forms of scholarship. For more information about JSTOR, please contact support@jstor.org. 


\title{
Shifting plaintiffs' fees versus increasing damage awards
}

\author{
Louis Kaplow*
}

Shifting victorious plaintiffs' fees to defendants and increasing damage awards are alternative ways to achieve similar results: increasing plaintiffs' incentives to sue and raising defendants' expected payments. This article shows that relying on higher damage awards is more efficient than shifting plaintiffs' fees. The reason is that fee shifting is more valuable for plaintiffs with higher litigation costs. Thus, it is possible to substitute higher damage awards for fee shifting in a manner that leaves deterrence unaffected while eliminating the suits of plaintiffs with the highest litigation costs.

\section{Introduction}

- Many statutes involve shifting victorious plaintiffs' fees or other costs to defendants in order to encourage the filing of lawsuits and increase liable defendants' expected payments. ${ }^{1}$ Increasing damage awards, as by using a multiplier, is another, less frequently employed, technique for accomplishing these results. This article demonstrates that using higher damage awards rather than shifting plaintiffs' fees enables one to produce the same expected penalty for defendants while reducing total litigation costs.

Section 2 proves the result in the context of a simple model of litigation. The intuition is that increasing damages rewards plaintiffs in a manner that depends upon their probability of victory, without regard to their litigation costs. In contrast, fee shifting is relatively more valuable to plaintiffs whose litigation costs are higher. ${ }^{2}$ As a result, substituting higher damage awards for fee shifting reduces the number of suits by eliminating those suits that involve the highest litigation costs. The total costs of litigation are thereby reduced. Deterrence is maintained because with higher damage awards, defendants pay more than they paid with fee shifting when they lose to plaintiffs who have low litigation costs.

This result is in the spirit of Becker's (1968) argument with respect to public law enforcement that it saves resources to achieve a given level of deterrence with a lower probability and a higher sanction. The result here involves fewer plaintiffs bringing suit,

* Harvard University and NBER.

I am grateful for comments from Bruce Hay, A. Mitchell Polinsky, Steven Shavell, and the referees.

${ }^{1}$ There are more than a hundred such federal statutes (in areas such as antitrust, environmental protection, and civil rights), and similar provisions in most states. (See Newberg, 1986.) As will be noted below, the analysis also is relevant to two-way fee shifting, as under the British rule (which is often proposed for ordinary civil litigation).

${ }^{2}$ The main reason litigation costs differ among plaintiffs is that their cases are not equally easy to prove. (Consider variation in the difficulty of tracing injuries to a source of pollution or proving whether an employer's action was motivated by impermissible discrimination.) Differences among lawyers (perhaps arising from differing agency costs) might also be significant. 
while those who sue and are successful recover more, on average. In this setting, however, the result arises in a rather different manner, and the reduction in private suits involves the more costly ones. Qualifications to the Becker strategy, notably concerning parties' risk aversion, remain applicable.

Section 3 extends the analysis to the case in which plaintiffs differ not only in their litigation costs but also in their probability of success. It also comments on two-way feeshifting schemes, settlement, and the endogeneity of litigation costs. Section 4 concludes by discussing the choice among methods of encouraging and discouraging suits. This section addresses the relationship between this article and recent literature on penalizing losing plaintiffs and decoupling defendants' payments and plaintiffs' awards.

\section{Model and analysis}

- Risk-neutral parties engage in litigation. Plaintiffs have a probability of victory of $p$. Possible plaintiffs differ in their litigation costs $c$, where $c$ has the distribution $f(c) .{ }^{3}$ The damages awarded are $d$, subject to a multiplier $m$. The defendant pays the share $s$ of a victorious plaintiff's costs. Finally, a defendant incurs litigation costs of $k$.

Thus, a plaintiff will sue if and only if

$$
\text { pmd }-c(1-p s) \geq 0 \text {. }
$$

In expression (1), pmd represents the expected judgment at trial and $c$ is the plaintiff's litigation cost, while a plaintiff's expected recovery of costs is $p s c$. From (1), it follows that a plaintiff will sue if and only if his litigation costs are below a threshold,

$$
c^{*}=\frac{p m d}{1-p s} \text {. }
$$

A defendant's behavior is assumed to be determined by the expected total costs as a result of the prospect of litigation. This aggregate expected cost is

$$
E=\int_{0}^{c^{*}}(p m d+p s c+k) f(c) d c .
$$

The integrand is the defendant's expected cost from a plaintiff of type $c$ who sues, weighted by the portion of plaintiffs who will be of that type. The expected award is pmd, the expected fee-shifting cost is psc, and the defendant's direct cost is $k$. Only plaintiffs with costs less than or equal to $c^{*}$ sue, which explains the upper limit of integration. ${ }^{4}$

The social objective is taken to be the minimization of expected litigation costs, subject to the constraint that the defendant's behavior is unaffected-i.e., that $E$ in (3) is constant. Expected social costs are

$$
L=\int_{0}^{c^{*}}(c+k) f(c) d c .
$$

For any suit that takes place, the total costs will be $c$ for the plaintiff (the amount will depend on the plaintiff's type) and $k$ for the defendant.

To prove the main result, consider the experiment of raising $m$ and reducing $s$ such that $c^{*}$ remains constant. That is, for a given increase in the damage award, reduce the extent of fee shifting in just the amount necessary to leave potential plaintiffs' decisions

${ }^{3}$ Litigation costs are treated as a unit, not distinguishing between fees and other costs, a distinction made in some fee- or cost-shifting rules.

${ }^{4}$ This problem can be interpreted in two ways. One is that a defendant injures a single individual. The distribution $f(\cdot)$ represents the probability that the person who is injured will have litigation costs of $c$. Alternatively, the defendant may injure many individuals, and $f(\cdot)$ would give the distribution of characteristics of those individuals. 
whether to sue unaffected. This involves determining $s$ as a function of $m$, so that the derivative of $c^{*}$ in (2) equals zero. Taking this derivative yields

$$
\frac{d s}{d m}=-\frac{1-p s}{p m} \text {. }
$$

Consider now expression (3), for $E$. The upper limit of integration, by construction, does not change as $m$ is increased and $s$ reduced according to (5). Thus, the only effect on the value of $E$ would be through the first component of the integrand:

$$
\begin{aligned}
\left.\frac{d}{d m}\right|_{s=s(m)}(p m d+p s c+k) & =p d+p c \frac{d s}{d m} \\
& =p d-\frac{p c(1-p s)}{p m} \\
& =\frac{1}{m}(p m d-c(1-p s)) \geq 0 .
\end{aligned}
$$

The final inequality follows from (1), the condition for the plaintiff to sue. Moreover, except when evaluated at $c^{*}$, the inequality will be strict. Thus, the integrand rises while the limits of integration remain the same; hence, $E$ rises.

Therefore, given an increase in $m$, the decrease in $s$ necessary to keep $E$ constantand thus the defendant's incentives the same-is greater than that given by (5). In other words, $s$ must fall by more than the amount necessary to keep $c^{*}$ constant. ${ }^{5}$ This fall in $s$ will, therefore, reduce $c^{*}$.

Consider, now, how this increase in $m$ and reduction in $s$ that keeps $E$ constant will affect social cost (4). The integrand is unaffected, but, as just noted, $c^{*}$ falls. Therefore, the social cost $L$ falls. Observe that this arises because fewer individuals sue (or, equivalently, the probability of a suit is lower). In particular, those plaintiffs who no longer find it profitable to sue are the ones with costs near the former, higher level of $c^{*}$-the highest-cost plaintiffs.

This demonstrates that the optimal value of $s$-the optimal extent to which the plaintiff's fees are shifted-is as low as possible. Note that negative shifting would, in principle, be optimal. It would involve taxing the victorious plaintiff's fees, with the tax paid to the defendant. Such a rule, combined with a higher damage award, would increase the extent to which higher-cost plaintiffs were deterred from suing. In the limit, one could achieve a desired level of deterrence with a minuscule probability of suit and an extremely high damage award, just as in the result due to Becker (1968) that optimal enforcement involves high sanctions applied with a low probability.

The usual caveats concerning the desirability of moving to extreme sanctions apply. In particular, the analysis here assumes that the parties are risk neutral. Substituting higher damage awards for the shifting of plaintiffs' fees discourages some suits while increasing plaintiffs' recoveries in others. ${ }^{6}$ This introduces more risk for both prospective plaintiffs and defendants. The optimal scheme, therefore, would stop short of extreme damage awards to the extent parties are risk averse and not fully insured. ${ }^{7}$

\footnotetext{
${ }^{5}$ It is straightforward that $s$ must fall by more than the amount given by (5) rather than less. When $s$ falls, $c^{*}$ and the integrand in (3) fall, both causing $E$ to fall.

${ }^{6}$ Since suit is less likely and the defendant's expected payment is the same, it must be that those who sue have higher expected recoveries (on average).

${ }^{7}$ See Polinsky and Shavell (1979). This qualification may be of limited applicability with regard to many fee-shifting statutes, notably in connection with civil rights and environmental legislation, where losses are often nonpecuniary and the primary purpose offered for fee shifting is to encourage suits that individual victims (each suffering small losses) have no incentive to bring and that may involve injunctive relief, leaving no common fund from which to compensate attorneys. In such instances, a statute could provide for a monetary award that does
} 


\section{Extensions}

- Plaintiffs with differing litigation costs and probabilities of success. One could extend the model to consider plaintiffs that differ in their probability of success. If this were the only dimension of difference (i.e., there was no heterogeneity with regard to litigation costs), fee shifting would be identical in its effect to a damage enhancement equal to the cost of litigation. When plaintiffs differ along both dimensions (the model would substitute $f(c, p)$, the joint distribution of $c$ and $p$ ), the result depends on whether courts can observe the probability of success (as has been assumed to be feasible in much past fee-shifting litigation ).$^{8}$ If they can, then the higher damage award, $m(p)$, could be selected so that the argument is precisely as in Section 2. If not, the same award enhancement must be applied in all cases, which makes the analysis more complex. It can be shown that an increase in damage awards and decrease in fee shifting that keeps deterrence unaffected eliminates some high-cost suits but encourages some low-cost suits. The typical suit would be a less costly one, but the total number of suits might fall, as in Section 2's model, or rise. ${ }^{9}$

$\square \quad$ Two-way fee shifting. The model could be extended to incorporate shifting a portion of successful defendants' fees as well. If one takes the extent of shifting of defendants' fees as given, the results are unaffected. Thus, it would reduce costs to replace two-way fee shifting with shifting of defendants' fees only, while increasing the damage award to leave defendants' expected payments the same. ${ }^{10}$

$\square$ Settlement and litigation costs. The savings from eliminating costly lawsuits are reduced to the extent that most cases settle. But as long as the amount of a settlement is positively related to trial awards, increasing the damage award and reducing the extent of fee shifting in a manner that keeps the defendant's expected payment the same will be relatively disadvantageous to plaintiffs with higher costs.

Shifting plaintiffs' fees and increasing damage awards may affect the likelihood of settlement differently. On one hand, asymmetric information concerning plaintiffs' litigation costs may make settlement less likely with fee shifting. On the other hand, substituting a higher damage award for fee shifting increases stakes, on average. When parties are relatively overoptimistic (i.e., if the plaintiff's estimate of the probability of victory exceeds the defendant's estimate), the plaintiff's minimally acceptable demand rises by more than does the defendant's maximum offer, which may make settlement less likely. ${ }^{11}$

not depend on the actual costs of the case, which would provide appropriate incentives to sue and equivalent deterrence without encouraging relatively costly cases.

${ }^{8}$ Until the Supreme Court's decision in City of Burlington v. Dague, 112 S. Ct. 2638 (1992), the practice was to enhance fee awards to account for the probability that no fee would have been recovered, since fee awards are contingent on plaintiffs' success. (The Court rejected this practice in part because a full adjustment would make the profitability of cases to lawyers-implicitly assuming their risk neutrality-independent of the probability of success. Under the new approach, cases will be unattractive to profit-motivated lawyers whenever the probability of success is less than one, unless plaintiffs supplement the fee award themselves.)

${ }^{9}$ This complication would be less important if classes of cases have similar probabilities of success (so that damage awards could be tailored to particular types of cases) or if one could, using the methods discussed in Section 4, separately discourage low-probability suits. (The low-cost suits encouraged by moving from fee shifting to higher damage awards are relatively low probability suits.)

${ }^{10}$ Shifting successful defendants' fees is a form of penalty on unsuccessful plaintiffs, as explored in Section 4, except that it provides more precise compensation to successful defendants while inducing defendants to spend more.

${ }^{11}$ This is necessarily true only in a simple model in which there is settlement if and only if a mutually beneficial settlement exists. It is not obvious that the possibility of fewer settlements should, in principle, weigh against a change. A technology that cut litigation costs in half would make settlement less likely. But one could tax trials in a manner that offset the effect on settlements. A similar tax on litigation expenditures here or in other contexts would increase settlements without increasing real resources devoted to lawsuits. 
Litigation costs in each case would also be affected. First, the increase in stakes that arises when substituting a higher damage award for fee shifting would tend to increase litigation expenditures per case. Second, eliminating fee shifting raises the expected marginal cost to the plaintiff of litigation expenditures, which would tend to decrease litigation expenditures per case. ${ }^{12}$ ( These effects would, in turn, affect the incentive to sue.) Finally, it is noteworthy that substantial litigation costs are incurred in the process of determining the appropriate fee award under fee-shifting rules. ${ }^{13}$

\section{Choosing among methods of encouraging and discouraging suits}

- Suits can be encouraged by raising damage awards, shifting victorious plaintiffs' fees to defendants, or subsidizing the filing of suits (e.g., by providing free legal services). Similarly, suits can be discouraged by reducing damage awards, shifting victorious defendants' fees to plaintiffs, imposing other penalties on losing plaintiffs, or charging filing fees. ${ }^{14}$ This article has shown that shifting victorious plaintiffs' fees to defendants rather than raising damage awards may be a perverse way to encourage suits, since the inducement tends to be more attractive to higher-cost plaintiffs. Shifting plaintiffs' fees achieves a given level of deterrence with more suits and, in particular, by encouraging suits that are relatively more expensive.

Recent literature has explored other ways of adjusting the rewards and penalties for bringing suit in a manner that would reduce litigation costs. Polinsky and Rubinfeld (1992, 1993 ) indicate that penalizing losing plaintiffs, while increasing the award for those who win, can reduce the number of suits necessary to achieve a given level of deterrence. ${ }^{15}$ (In particular, this change makes filing a suit less attractive to plaintiffs with low probabilities of success while increasing the net expected award to those with high probabilities. ${ }^{16}$ ) Polinsky and Che (1991) demonstrate how decoupling-making the defendant pay damages that differ from what a plaintiff receives-can achieve a given level of deterrence with fewer suits. (For example, increasing the defendant's payment and decreasing prospective plaintiffs' recoveries induces fewer to sue, but maintains deterrence by making the defendant pay more in each successful suit.)

This literature and the present article offer some basis for choosing among the ways of affecting the incentive to sue. ${ }^{17}$ Filing subsidies increase deterrence by encouraging suits, without particular regard for litigation costs or the merits. Shifting plaintiffs' fees to defendants has a relatively greater effect for high-probability cases, but this method of increasing deterrence also increases litigation, with the additional suits being filed by plaintiffs with higher legal costs. In contrast, increasing damage awards for victorious plaintiffs (or penalizing losing plaintiffs, directly or by shifting defendants' fees) targets plaintiffs solely according to their probability of success. Decoupling allows one to discourage costlier and lowerprobability suits. These latter alternatives, therefore, allow a given level of deterrence to be

\footnotetext{
${ }^{12}$ Katz (1987) analyzes effects of both types.

${ }^{13}$ Courts must determine the amount of work effort, whether the work effort was appropriate, how the effort should be valued, and what if any multiplier should be applied to account for risk (see footnote 8 ).

${ }^{14}$ Obviously, many other changes in legal rules would affect the incentive to file suits.

${ }^{15} \mathrm{Katz}$ (1990) discusses penalizing losing plaintiffs, but does not consider increasing awards to those who win.

${ }^{16}$ Polinsky and Rubinfeld's articles $(1992,1993)$ are close in spirit to the present article. They focus on discouraging low-probability plaintiffs, while this article focuses on discouraging high-cost plaintiffs. (Another difference is that the model here allows for a continuum of plaintiffs, making the benefit of an extreme solution, discussed at the end of Section 2, more apparent.)

${ }^{17}$ The discussion here is limited to policies that directly affect the decision whether to sue, rather than those concerned with settlement, although both types of policies obviously affect both suit and settlement.
} 
achieved with fewer, less costly suits. ${ }^{18}$ It was noted, however, that parties' risk aversion may qualify such results.

\section{References}

$\rightarrow$ BeCKer, G.S. "Crime and Punishment: An Economic Approach." Journal of Political Economy, Vol. 76 (1968), pp. $169-217$.

NewBerg, H.B. Attorney Fee Awards. New York: McGraw-Hill, 1986.

$\rightarrow$ KATZ, A. "Measuring the Demand for Litigation: Is the English Rule Really Cheaper?" Journal of Law, Economics, and Organization, Vol. 3 (1987), pp. 143-176.

- "The Effect of Frivolous Lawsuits on the Settlement of Litigation." International Review of Law and Economics, Vol. 10 (1990), pp. 3-27.

POLINSKY, A.M. AND CHE, Y.-K. "Decoupling Liability: Optimal Incentives for Care and Litigation." RAND Journal of Economics, Vol. 22 (1991), pp. 562-570.

- AND Rubinfeld, D.A. "Optimal Awards and Penalties When Some Suits Are Frivolous." Stanford Law School, John M. Olin Program in Law and Economics Working Paper No. 93, 1992.

AND - "Sanctioning Frivolous Suits: An Economic Analysis." Stanford Law School, John M. Olin Program in Law and Economics Working Paper No. 103, 1993.

$\longrightarrow$ and Shavell, S. "The Optimal Tradeoff Between the Probability and Magnitude of Fines." American Economic Review, Vol. 69 (1979), pp. 880-891.

${ }^{18}$ When cases are heterogeneous and cannot be distinguished by adjudicators, common damage multipliers, fee-shifting rules, and the like must be applied. The result is that there will be excessive litigation and deterrence for some acts and inadequate litigation and deterrence for others. It is possible in such a setting that a different mix of rules might be appropriate than otherwise, although it is not obvious which methods of encouraging litigation thus appear more or less attractive. 